\title{
PENGGUNAAN TAUGE YANG BERBEDA SEBAGAI SUMBER NITROGEN PADA PEMBUATAN NATA DE YAM
}

\author{
Wenny Surya Murtius, Alfi Asben, Risa Meutia Fiana dan Indah Khairun Nisa \\ Fakultas Teknologi Pertanian, Universitas Andalas \\ Email: wenny.murtius@gmail.com
}

\begin{abstract}
ABSTRAK
Penelitian ini menggunakan tauge dari kacang hijau sebagai sumber nitrogen untuk memproduksi nata dari bengkoang. Tauge yang digunakan adalah dari 4 kondisi tauge yang berbeda, dengan tujuan penelitian menentukan kondisi tauge terbaik sebagai sumber nitrogen berdasarkan karakteristik nata yang dihasilkan. Penelitian ini menggunakan metode eksploratif dengan 4 perlakuan dan 2 ulangan. Perlakuan pada penelitian ini menggunakan kondisi tauge berbeda diantaranya adalah; tunas tauge, tauge segar, tauge akan busuk dan tauge layu. Parameter yang digunakan dalam penelitian ini adalah total gula dan nitogen pada bahan baku, serat kasar, rendemen, ketebalan, berat, tekstur dan organoleptik meliputi; warna, tekstur, aroma dan rasa. Hasil penelitian menunjukkan bahwa kondisi tauge yang berbeda menyebabkan serat kasar, rendemen, ketebalan, berat, tekstur dan snsory yang berbeda. Berdasarkan karakteristik fisik dan kimia produk perlakuan D (tauge layu) merupakan produk terbaik dengan rata-rata nilai serat kasar 5,82\%, rendemen $81,73 \%$, ketebalan 1,05 cm, berat 335,07 g, tekstur 123,58 N/cm.

Kata kunci-tauge kacang hijau; bengkoang; nitrogen; nata bengkoang
\end{abstract}

\section{PENDAHULUAN}

Nata merupakan produk hasil fermentasi dari bakteri Acetobacter xylinum yang diinokulasi pada media yang mengandung gula. Menurut Suwijah (2011), Acetobacter xylinum akan membentuk nata dengan cara menyerap glukosa yang terkandung di dalam bahan dan akan menggabungkannya dengan asam lemak, membentuk prekursor pada membran sel dan kemudian keluar bersama dengan enzim yang mempolimerasikan glukosa menjadi selulosa diluar sel.

Seiring berkembangnya teknologi, bahan baku nata semakin beragam, dapat dibuat dari ampas tahu, buah jambu mete, lidah buaya atau kulit nanas dan juga bengkuang. Nata de yam merupakan jenis nata yang dibuat dengan memanfaatkan sari bengkuang sebagai bahan pembuatan nata. Yeni $e t$ al (2013) menyatakan kadar gula yang terkandung dalam bengkuang segar sekitar 5,2 \%. Sedangkan kebutuhan untuk pertumbuhan Acetobacter xylinum adalah 15-20\% sehingga perlu penambahan gula agar pertumbuhan Acetobacter xylinum optimal. Nata de yammemiliki kandungan serat yang lebih tinggi dibandingkan nata de coco. Menurut Wardhana (2016), kandungan serat kasar yang terkandung di dalan nata de yammencapai 3,24\% sedangkan pada nata de coco hanya sebesar 2,83\% sehingga nata de yam lebih baik untuk pencernaan.

Acetobacter xylinum di dalam pertumbuhannya membutuhkan nutrisi seperti $\mathrm{C}, \mathrm{H}, \mathrm{N}$ serta mineral. Bengkuang (Pachyrhizus erosus) mengandung sebagian sumber nutrisi yang dibutuhkan oleh Acetobacter xylinum, akan tetapi kebutuhan seperti sumber $\mathrm{C}$ dan $\mathrm{N}$ perlu ditambahkan agar kualitas nata yang dihasilkan optimal. Menurut Pambayun (2002); Agustin (2013), bakteri Acetobacter xylinum dapat membentuk nata jika ditumbuhkan dalam media yang sudah mengandung karbon (C) dan nitrogen $(\mathrm{N})$ melalui proses yang terkontrol. Unsur $\mathrm{C}$ sangat dibutuhkan untuk memenuhi kebutuhan energi bakteri agar tumbuh optimal sedangkan unsur $\mathrm{N}$ berperan dalam membentuk protein. Protein akan membantu mempercepat pertumbuhan sel dan membantu pembentukan enzim yang dihasilkan oleh bakteri dalam membentuk nata. Kebutuhan Acetobacter xylinum terhadap karbon dapat ditambahkan dengan sukrosa, glukosa dan fruktosa (Hamad dan Kristiono, 2013).

Sumber nitrogen dapat berasal dari bahan organik maupun anorganik. Bahan organik dapat berasal dari sari kecambah kacang hijau dan sari kecambah kacang kedelai (Hamad et al, 2014). Arifiani et al (2015) menyatakan tauge segar memiliki kandungan nitrogen 20,5\% sampai $21 \%$. Sumber nitrogen dari sari kecambah kacang hijau berkisar 20-35\% volume medium (Triyono, 2010). Tauge yang digunakan yaitu $20 \%$ dari volume sari bengkuang. Lempang (2007) mengemukakan bahwa semakin banyak jumlah nutrien yang ditambahkan dalam medium maka rendemen nata akan 
semakin meningkat sampai batas optimum. Apabila ketersediaan nutrien dalam medium yang jumlah inokulasinya terlalu banyak, maka nutrien tersebut justru dapat bersifat toksik terhadap mikrobia, sehingga produksi nata tidak maksimal.

Tauge merupakan perkecambahan dari kacang hijau yang mengalami perubahan fisik dan kimiawi yang disebabkan oleh proses metabolisme. Perkecambahan merupakan suatu proses keluarnya bakal tanaman dari lembaga disertai dengan terjadinya mobilisasi cadangan makanan dari jaringan penyimpan atau keping biji ke bagian vegetatif. Selama perkecambahan terjadi hidrolisa protein, karbohidrat dan lemak. Pada proses perkecambahan terjadi beberapa kandungan pati diubah menjadi bagian yang lebih kecil yaitu glukosa dan maltosa. Molekul protein dipecah menjadi asam amino sehingga dalam kecambah terjadi kenaikan konsentrasi asam amino (Winarno, 2004).

Pertiwi (2013) menyatakan bahwa semakin lama umur perkecambahan maka kandungan proteinnya akan mengalami penurunan, karena pada saat pertumbuhan kecambah, nitrogen (protein) digunakan untuk pembentukan struktur yang baru sejalan dengan bertambahnya umur dan tahapan perkecambahan. Widajati (2014) menyatakan bahwa dalam proses perkecambahan terjadi berbagai perubahan biologis yaitu perubahan senyawa kompleks menjadi senyawa yang lebih sederhana yang telah siap dimanfaatkan oleh embrio untuk pertumbuhan lebih lanjut. Selama terjadinya proses perkecambahan, kandungan karbohidrat diubah menjadi dekstrin atau bagian yang lebih kecil yaitu dalam bentuk gula maltosa, protein yang besar diubah menjadi asam amino.

Tauge yang ditemukan dikehidupan sehari-hari beragam ada yang masih dalam bentuk tunas, ada yang segar, ada yang layu dan juga ada dalam bentuk kering. Oleh karena itu penulis alam melakukan penelitian dengan pengamatan penambahan sumber nitrogen yang berasal dari tunas tauge, tauge segar, tauge layu dan tauge kering. Penggunaan tauge yang berbeda diharapkan dapat menambah nilai ekonomis dari tauge yang ada dipasaran, kemudian dapat menjadi terobosan baru dalam pemanfaatan tauge untuk menghasilkan perlakuan terbaik dalam pembuatan nata.

\section{METODOLOGI PENELITIAN}

\section{A. Bahan dan Alat}

Bahan utama yang digunakan dalam penelitian ini adalah bengkuang varietas Kota Padang, Sumatera Barat, tunas tauge yang berumur 2 hari, tauge segar, tauge akan busuk dan tauge layu, starter Acetobacter xylinum dan air. Bahan-bahan kimia yang akan digunakan adalah Akuades, $\mathrm{H}_{2} \mathrm{SO}_{4}$, $\mathrm{NaOH}, \mathrm{NaClO}_{2}, \mathrm{~K}_{2} \mathrm{SO}_{4} 10 \%$, atanol, aseton dan asam asetat glasial. Alat yang digunakan dalam penelitian ini adalah timbangan, wadah, pisau, kompor, pengaduk, kain penyaring, blender, neraca analitik, jangka sorong, $\mathrm{pH}$ meter dan karet.

\section{B. Metode Penelitian}

Metode penelitian yang digunakan pada penelitian ini adalah metode eksploratif. Penelitian dilakukan dengan 4 perlakuan dan 2 kali ulangan. Perlakuan yang diberikan adalah penggunaan 4 tauge yang berbeda sebagai sumber karbon dalam pembuatan nata. Perbedaan penggunaan tunas tauge, tauge segar, tauge layu dan tauge kering akan mempengaruhi kualitas nata yang dihasilkan.

\section{Pelaksanaan Penelitian \\ 1. Persiapan Bahan Baku}

Bengkuang dikupas dan ditimbang $1 \mathrm{~kg}$. Bengkuang yang digunakan adalah bengkuang yang masih segar. Bengkuang segar dapat dilihat dari kondisi kulitnya yang masih mulus dan belum ada bercak hitam, kemudian bagian tampuknya belum mencoklat. Bengkuang yang telah dikupas di potong kecil-kecil dan diblender dengan ditambahkan sedikit air agar memudahkan proses penghalusan bengkuang. Perbandingan antara bengkuang dengan air adalah 1:1. Campuran tersebut kemudian diperas dengan menggunakan kain saring dan diperoleh sari bengkuang. Sebelum digunakan sari bengkuang diendapkan selama 2 jam hingga terpisah antara pati dan sari bengkuang dan sari bengkuang siap untuk digunakan sebagai media nata.

\section{Penyiapan Tauge}

Disiapkan botol plastik yang telah dilubangi bagian bawah dan bagian samping tutup rapat supaya cahaya tidak masuk ke dalam botol. Setelah itu kacang hijau dimasukkan ke dalam botol 
sebanyak 10 g. Kacang hijau yang dimasukkan ke dalam botol disiram setiap 2 jam. Untuk mendapatkan tunas tauge, kacang hijau disiram selama 2 hari. Setelah 2 hari tunas tauge siap dipanen. Tauge segar dipanen pada hari ke-4. Tauge akan busuk dipanen pada hari ke-4 dan dibiarkan ditempat terbuka selama 2 hari sehingga tauge berwarna kecoklatan. Tauge layu dipanen pada hari ke-4 dan ditiriskan, setelah itu disimpan pada plastik hitam atau gelap selama 3 hari, sehingga tauge mengkerut dan kadar air pada tauge layu rendah dari tauge segar (50\% untuk tauge layu dan $88 \%$ untuk tauge segar).

\section{Pembuatan Sari (Hastuti, 2015)}

Tauge dibersihkan dengan menggunakan air mengalir kemudian ditimbang sebanyak 100 gram. Tauge yang telah bersih lalu ditambahkan air sebanyak $100 \mathrm{ml}$ dan dihancurkan dengan menggunakan blender. Tauge yang telah dihancurkan didiamkan kemudian disaring hingga didapatkan sarinya.

\section{Pengembangbiakan starter Modifikasi (Pambayun, 2002).}

Air kelapa sebanyak $500 \mathrm{ml}$ dicampur dengan 50 gram gula pasir putih, $100 \mathrm{ml}$ sari kecambah kacang hijau dan asam asetat glasial 98\% hingga mencapai $\mathrm{pH} 4$. Bahan yang telah dicampur tersebut kemudian direbus hingga mendidih dan dipertahankan selama 5-10 menit. Masukkan bahan tersebut ke dalam botol kaca yang telah disterilkan dan didiamkan hingga benar-benar dingin. Setelah itu diinokulasikan biakan Acetobacter xylinum sebanyak $50 \mathrm{ml}$ dan fermentasi selama 7 hari hingga terbentuk lapisan putih, licin dan tebal pada permukaan media.

\section{Formulasi Bahan}

Bahan baku utama dalam pembuatan nata dari bengkoang adalah bengkoang, sari tauge kacang hijau sebagai sumber nitrogen, serta penambahan sukrosa sebagai sumber karbon. Asam asetat glasial ditambah dengan tujuan untuk mencapai $\mathrm{pH}$ optimum media untuk pertumbuhan Acetobacter xylinum. Formulasi lengkap pembuatan nata de yam dapat dilihat pada Tabel 1 berikut

Tabel 1. Formulasi Bahan Baku Nata de Yam

\begin{tabular}{lcccc}
\hline \multirow{2}{*}{ Bahan } & \multicolumn{4}{c}{ Perlakuan } \\
\cline { 2 - 5 } & $\mathrm{A}$ & $\mathrm{B}$ & $\mathrm{C}$ & $\mathrm{D}$ \\
\hline Sari Bengkuang $(\mathrm{ml})$ & 500 & 500 & 500 & 500 \\
Sari Tauge $(\%)$ & 60 & 100 & 100 & 100 \\
Acetobacter xylinum $(\mathrm{ml})$ & 60 & 60 & 60 \\
Asam Asetat Glasial $(\mathrm{ml})$ & 5 & 5 & 5 & 5 \\
Penambahan sukrosa $(\mathrm{g})$ & 50 & 50 & 50 & 50 \\
\hline Keterangan: Jumlah sari tauge yang digunakan $20 \%$ & dari jumlah sari bengkuang
\end{tabular}

\section{Pembuatan Nata}

Pada pembuatan nata dari bahan baku bengkuang penulis mengambil acuan dari prosedur kerja peneliti sebelumnya. Menurut Margaretha (2015), proses pembuatan nata de yam sebagai berikut:

1. Dimasukkan sari bengkuang, tauge dan gula yang telah disiapkan ke dalam wadah sesuai dengan formulasi

2. Dipanaskan sampai susu $100^{\circ} \mathrm{C}$ dan pertahankan selama 5-10 menit

3. Ditambahkan asam asetat glasial hingga mencapai $\mathrm{pH} 4$

4. Dituangkan ke dalam nampan yang telah disterilisasi dan ditutup dengan koran hingga suhu media mencapai suhu ruang atau pada kisaran $30^{\circ} \mathrm{C}$

5. Setelah suhu media dingin, diinokulasikan biakan Acetobacter xylinum ke dalam media dan tutup kembali dengan kertas koran polos. Difermentasi selama 8 hari dan nata siap untuk dipanen.

\section{Pengamatan}

Pengamatan terhadap penelitian ini meliputi 3 bagian yaitu pengamatan bahan baku, media dan pengamatan produk. Pada bahan baku dilakukan pengamatan kadar gula pada bengkuang dan kadar nitrogen pada tauge, pada media dilakukan uji $\mathrm{pH}$ dan pada produk dilakukan pengamatan kadar serat kasar, rendemen, ketebalan, berat, tekstur dan organoleptik. 


\section{HASIL DAN PEMBAHASAN}

\section{A. Analisis Bahan Baku}

Uji kadar glukosa pada bengkuang bertujuan untuk menentukan penambahan gula pada saat pembuatan nata de yam. Berdasarkan pengujian yang telah dilakukan kandungan glukosa pada bengkuang sebesar 4,98\% $\pm 0,16$. Masran (2019) menyatakan penambahan gula pasir sebanyak $10 \%$ dari jumlah bahan yang digunakan menghasilkan nata dengan optimal.

Uji nitrogen dilakukan pada tauge yang digunakan. Nitrogen adalah salah satu faktor untuk merangsang pertumbuhan dan aktivitas bakteri Acetobacter xylinum. Unsur nitrogen dalam pembuatan nata sangat dibutuhkan untuk pertumbuhan bakteri Acetobacter xylinum. Semakin meningkat pertumbuhan dan aktivitas Acetobacter xylinum, maka produksi selulosa yang terbentuk akan semakin tinggi dan membuat nata menjadi tebal. Kadar nitrogen pada tauge yang berbeda dapat dilihat pada Tabel 2.

\begin{tabular}{ll} 
Tabel 2. Hasil Pengujian Kadar Nitrogen di dalam Tauge \\
\hline Perlakuan & Nitrogen $(\%) \pm$ SD \\
\hline A $=$ Tunas & $2,43 \pm 0,58$ \\
B = Segar & $3,22 \pm 1,8$ \\
C = Akan busuk & $2,81 \pm 1,09$ \\
D = Layu & $3,06 \pm 1,50$ \\
\hline
\end{tabular}

Pada Tabel 2 dapat dilihat kadar nitrogen yang tertinggi pada tauge segar sebesar 3,22\% dan kadar nitrogen terendah pada tauge tunas sebesar 2,43\%. Hal ini disebabkan kandungan gizi pada biji sebelum dikecambahkan berada dalam bentuk tidak aktif atau terikat, sedangkan pada proses perkecambahan bentuk tersebut diaktifkan sehingga mudah dimanfaatkan oleh bakteri. Astawan (2005) dalam Maulana (2010) menyatakan pada saat perkecambahan, terjadi hidrolisis karbohidrat, protein dan lemak menjadi senyawa-senyawa yang lebih sederhana sehingga mudah dimanfaatkan oleh bakteri. Walaupun beberapa kandungan gizi dalam kecambah tauge memiliki kadar lebih rendah dibandingkan biji kacang hijau, tetapi kandungan gizi tersebut dalam bentuk senyawa terlarut.

\section{B. Analisis Media}

Pada Tabel 3 dapat diuraikan bahwa $\mathrm{pH}$ awal substrat belum mendekati nilai $\mathrm{pH}$ optimal pertumbuhan bakteri Acetobacter xylinum. Untuk mencapai $\mathrm{pH}$ optimal pertumbuhan bakteri Acetobacter xylinum dilakukan penambahan asam asetat glacial konsentrasi $98 \%$ ke dalam substrat sari bengkuang. Pengukuran $\mathrm{pH}$ dilakukan dengan alat $\mathrm{pH}$ meter yang telah dikalibrasi terlebih dahulu. Pada setiap perlakukan, $\mathrm{pH}$ awal media fermentasi diseragamkan agar tidak memberikan pengaruh yang berbeda terhadap hasil penelitian yang dilakukan dan pertumbuhan bakteri Acetobacter xylinum berlangsung optimal.

Tabel 3. Rata-rata pH Media Awal Fermentasi

\begin{tabular}{lc}
\hline Perlakuan & $\mathrm{pH} \pm \mathrm{SD}$ \\
\hline $\mathrm{A}=$ Tunas & $6,25 \pm 0,07$ \\
$\mathrm{~B}=$ Segar & $6,3 \pm 0,14$ \\
$\mathrm{C}=$ Akan busuk & $6,4 \pm 0,14$ \\
$\mathrm{D}=$ Layu & $6,35 \pm 0,07$ \\
\hline
\end{tabular}

\section{Analisis Produk}

\section{Ketebalan nata de yam}

Berdasarkan penelitian yang telah dilakukan rata-rata ketebalan yang dihasilkan pada setiap perlakuan dapat dilihat pada Tabel 4. Penggunaan tauge yang berbeda dalam pembuatan nata de yam berpengaruh terhadap ketebalan nata yang dihasilkan. Pada penelitian ini diperoleh ketebalan tertinggi pada perlakuan D (penggunaan tauge layu) dengan rata-rata ketebalan $1,05 \mathrm{~cm}$, kemudian perlakuan B (penggunaan tauge segar) dengan rata-rata ketebalan $0,97 \mathrm{~cm}$, selanjutnya perlakuan $\mathrm{C}$ (penggunaan tauge layu) dengan rata-rata ketebalan $0,93 \mathrm{~cm}$ dan ketebalan paling rendah pada perlakuan $\mathrm{A}$ (penggunaan tunas tauge) dengan rata-rata ketebalan $0,79 \mathrm{~cm}$. 


\begin{tabular}{|c|c|}
\hline \multicolumn{2}{|c|}{ Tabel 4. Nilai Rata-rata Ketebalan Nata de yam } \\
\hline Perlakuan & Ketebalan $(\mathrm{cm}) \pm \mathrm{SD}$ \\
\hline $\mathrm{A}=$ Tunas & $0,79 \pm 0,063$ \\
\hline B = Segar & $0,97 \pm 0,106$ \\
\hline $\mathrm{C}=$ Akan busuk & $0,93 \pm 0,098$ \\
\hline $\mathrm{D}=$ Kering & $1,05 \pm 0,003$ \\
\hline
\end{tabular}

Menurut Alexander (1994) dalam Masran (2019), jumlah kandungan N yang tinggi akan meningkatkan emisi dari nitrogen sebagai amonium yang dapat menghalangi perkembangbiakan bakteri sedangkan jumlah unsur $\mathrm{N}$ yang terlalu rendah akan mengakibatkan proses perombakan akan berjalan lambat karena mikroorganisme akan kekurangan suplemen dalam pertumbuhannya. Hal yang menyebabkan ketebalan nata berbeda yaitu kandungan nitrogen yang tersediapada media yang berbeda. Dalam pembuatan nata de yam, nitrogen yang dibutuhkan oleh bakteri Acetobacter xylinum sebagai komponen penting untuk biosistesis selulosa (Hamad dan Kristiono, 2013). Kandungan nitrogen pada tunas tauge sebesar $2,43 \%$, tauge segar sebesar 3,22\%, tauge layu sebesar $2,81 \%$ dan tauge kering sebesar 3,06\%.

Berdasarkan uji rasio $\mathrm{C} / \mathrm{N}$ yang dilakukan media pada perlakuan $\mathrm{D}$ (Tauge kering) didapatkan hasil 10,25 $\pm 0,108$. Nilai karbon pada perlakuan D (Tauge kering) sebesar 30,64\% $\pm 0,53$ dan nilai nitrogen total 2,99\% $\pm 0,09$. Menurut Shewfelt (2005) dalam Masran (2019), perbandingan jumlah $\mathrm{C} / \mathrm{N}$ optimal dalam proses biodegradasi bahan organik adalah 10:1. Jika dilihat dari rasio $\mathrm{C} / \mathrm{N}$ perlakuan D (Tauge kering) memiliki rasio $\mathrm{C} / \mathrm{N}$ dengan perbandingan nilai 10:1, sehingga waktu yang dibutuhkan lebih cepat untuk proses perombakan glukosa menjadi selulosa oleh bakteri Acetobacter xylinum.

\section{Rendemen Nata de yam}

Berdasarkan Tabel 5 diatas dapat dilihat bahwa penggunaan tauge yang berbeda mempengaruhi rendemen nata yang dihasilkan. Jumlah rendemen tertinggi diperoleh pada perlakuan D (penggunaan tauge layu) dengan nilai rendemen mencamain $81,73 \%$, diikuti perlakuan B (penggunaan tauge segar) dengan nilai rendemen 78,55\%, selanjutnya perlakuan $\mathrm{C}$ (penggunaan tauge akan busuk) dengan nilai rendemen $74,94 \%$ dan nilai rendemen terendah pada perlakuan A (pengguana tunas tauge) dengan nilai rendemen $72,38 \%$. Nilai rata-rata rendemen nata de yam yang dihasilkan dapat dilihat pada tabel 5.

Tabel 5. Nilai Rata-rata Rendemen Nata de yam

\begin{tabular}{lc}
\hline \multicolumn{1}{c}{ Perlakuan } & Rendemen $(\%) \pm$ SD \\
\hline A $=$ Tunas tauge & $72,38 \pm 2,67$ \\
$\mathrm{~B}=$ Tauge segar & $78,55 \pm 2,64$ \\
$\mathrm{C}=$ Tauge layu & $74,94 \pm 11,02$ \\
$\mathrm{D}=$ Tauge kering & $81,73 \pm 7,41$ \\
\hline
\end{tabular}

Faktor yang mempengaruhi rendemen nata yang dihasilkan adalah faktor nutrisi karena nutrisi mempunyai pengaruh yang kuat terhadap sifat, hasil dan komposisi selulosa yang terbentuk. Sumber nutrisi yang dimaksud yaitu kecukupan sumber karbon dan sumber nitrogen. Sumber karbon dan sumber nitrogen dalam media dapat memberikan pengaruh untuk merangsang mikroorganisme dalam mensintesa selulosa agar menghasilkan nata dengan ikatan selulosa yang kuat.

\section{Berat Nata de yam}

Berdasarkan Tabel 6 dapat dilihat bahwa penggunaan tauge yang berbeda berpengaruh terhadap total berat nata disetiap nampan. Berat tertinggi diperoleh pada perlakuan D (penggunaan tauge layu) dengan berat 335,07 g, disusul dengan perlakuan B (penggunaan tauge segar) dengan berat 322,05 g, selanjutnya perlakuan $\mathrm{C}$ (penggunaan tauge akan busuk) dengan berat 307,25 dan berat terendah pada perlakuan A (penggunaan tunas tauge) dengan berat 296,76 g. Pengujian berat yang telah dilakukan pada nata de Yam dengan menggunakan tauge yang berbeda dapat dilihat Tabel 6. 
Tabel 6. Nilai Rata-rata Berat Total Nata de yam setiap nampan.

\begin{tabular}{ll}
\hline Perlakuan & Berat $(\mathrm{g}) \pm \mathrm{SD}$ \\
\hline $\mathrm{A}=$ Tunas tauge & $296,76 \pm 10,97$ \\
$\mathrm{~B}=$ Tauge segar & $322,05 \pm 10,81$ \\
$\mathrm{C}=$ Tauge busuk & $307,25 \pm 45,18$ \\
$\mathrm{D}=$ Tauge layu & $335,07 \pm 30,37$ \\
\hline
\end{tabular}

Berat nata yang dihasilkan sejalan dengan berat nata yang dihasilkan sejalan dengan jumlah rendemen dan ketebalan nata yang dihasilkan. Perbedaan berat nata pada setiap perlakuan juga dipengaruhi oleh unsur nitrogen yang terkandung didalam media. Pada penelitian yang telah dilakukan dapat dilihat berat nata tertinggi didapat pada perlakuan D (tauge layu) sebesar 335,07 g. Dilihat dari kandungan nitrogen yang terdapat pada perlakuan D (tauge layu) sebesar 3,06\% dan pada perlakuan B (tauge segar) memiliki kandungan nitrogen lebih tinggi sebesar 3,22\% dengan berat 322,05. Evi et al (2008) menyatakan bahwa penggunaan nitrogen yang berlebihan pada media yang sama dan penambahan gula dengan konsentrasi yang sama dapat menyebabkan ketidak seimbangan nutrisi dalam media, yang mana peningkatan konsentrasi nitrogen tidak diikuti dengan peningkatan konsentrasi zat-zat lainnya, sehingga pada penggunaan nitrogen yang lebih tinggi pada perlakuan B (tauge segar) kemungkinan banyak nitrogen yang tidak termanfaatkan.

Penambahan nitrogen ke dalam media akan mempercepat bakteri masuk ke dalam fase pertumbuhan eksponensial (Kuncara, 2017). Menurut Pambayun (2002), pada fase eksponensial bakteri Acetobacter xylinum mengalami laju pertumbuhan yang lebih cepat dan konstan yang menyebabkan adanya peningkatan populasi bakteri Acetobacter xylinum. Pada fase pertumbuhan eksponensial bakteri Acetobacter xylinum mengeluarkan enzim ekstraseluler polimerase sebanyakbanyaknya untuk menyusun monomer glukosa menjadi selulosa.

\section{Kadar Serat Kasar}

Berdasarkan tabel di bawah ini dapat dilihat perbedaan kadar serat kasar yang pada nata de yam dengan penggunaan tauge yang berbeda. Kadar serat tertinggi diperoleh pada perlakuan D (Penggunaan tauge layu) dengan jumlah serat kasar mencapau 5,82\%, disusul dengan perlakuan B (penggunaan tauge segar) jumlah serat kasar 5,45\%, selanjutnya perlakuan $\mathrm{C}$ (penggunaan tauge akan busuk) dengan jumlah serat kasar 4,98\% dan jumlah serat kasar terendah pada perlakuan A (penggunaan tunas tauge) dengan jumlah serat kasar 4,50\%. Rata-rata kadar serat kasar yang terdapat pada nata de yam dapat dilihat pada tabel 7.

Tabel 7. Rata-rata Kadar Serat Kadar Nata de yam

\begin{tabular}{cc}
\hline Perlakuan & Kadar Serat Kasar $(\%) \pm$ SD \\
\hline A = Tunas tauge & $4,50 \pm 0,049$ \\
B = Tauge segar & $5,45 \pm 0,007$ \\
C = Tauge akan busuk & $4,98 \pm 0,042$ \\
D = Tauge layu & $5,82 \pm 0,106$ \\
\hline
\end{tabular}

Hal ini berhubungan dengan ketebalan, berat serta rendemen dari nata, karena semakin tebal nata yang dihasilkan maka, semakin banyak selulosa yang terbentuk. Kemampuan bakteri Acetobacter xylinum dalam membentuk jaringan selulosa yang akan membentuk nata sangat bergantung dengan komposisi media yang digunakan. Nitrogen merupakan salah satu nutrisi yang harus ada di dalam media, sehingga bakteri Acetobacter xylinum dapat memfermentasi media menjadi nata secara maksimal (Kuncara, 2017).

Nata terbentuk karena aktifitas bakteri Acetobacter xylinum yang merombak sukrosa menjadi selulosa dalam media yang disediakan. Penambahan nitrogen dalam media akan dimanfaatkan oleh bakteri Acetobacter xylinum untuk pembentukan sel-sel baru. Semakin banyak sel yang terbentuk akan memungkinkan pembentukan serat nata yang lebih banyak. Serat nata berkaitan dengan kandungan kadar air di dalamnya. Semakin tinggi serat kasar nata yang terbentuk maka air yang terperangkap di dalamnya menjadi semakin sedikit. Ini disebabkan karena semakin tinggi serat kasar, maka air yang terperangkap diantara selulosa semakin sedikit (Rosalia, 2016). 


\section{Tekstur Nata de yam}

Dari data di bawah ini dapat dilihat bahwa kekenyalan terletak pada perlakuan D (tauge layu) dengan nilai kekenyalan 123,58 (N/cm), disusul perlakuan B (tauge segar) dengan nilai kekenyalan $78,34 \mathrm{~N} / \mathrm{cm}$, selanjutnya perlakuan $\mathrm{C}$ (tauge akan busuk) dengan nilai 63,39 N/cm dan yang terakhir perlakuan A (tunas tauge) dengan nilai $47,17 \mathrm{~N} / \mathrm{cm}$. Rata-rata nilai tekstur pada nata de yam dapat dilihat pada Tabel 8.

Tabel 8. Nilai Rata-rata Tekstur Nata de yam

\begin{tabular}{ll}
\hline Perlakuan & Tekstur $(\mathrm{N} / \mathrm{cm}) \pm \mathrm{SD}$ \\
\hline $\mathrm{A}=$ Tunas Tauge & $47,17 \pm 1,94$ \\
$\mathrm{~B}=$ Tauge segar & $78,34 \pm 3,14$ \\
$\mathrm{C}=$ Tauge layu & $63,39 \pm 4,43$ \\
$\mathrm{D}=$ Tauge kering & $123,58 \pm 4,87$ \\
\hline
\end{tabular}

Kekenyalan pada nata erat kaitannya dengan kadar serat yang terkandung di dalam nata yang diperoleh. Penggunaan sumber nitrogen organik berupa tauge yang berbeda mempengaruhi tekstur kekenyalan nata yang dihasilkan. Menurut Hubies (1996) dalam Rosalia (2016), perbandingan antara serat kasar dan kekenyalan adalah berbanding lurus, artinya semakin banyak kandugan serat kasar semakin kenyal tekstur nata. Perbedaan nilai kekenyalan pada setiap perlakuan dapat disebabkan karena adanya komponen serat yang membentuk jaring-jaring yang memperangkap air dan menyebabkan struktur nata menjadi agar. Kandungan mineral dalam media juga menentukan tingkat kekenyalan (Nur, 2009).

\section{Uji Organoleptik}

Pengujian organoleptik merupakan suatu proses identifikasi suatu produk yang dihasilkan melalui panca indera manusia. Uji organoleptik dilakukan untuk menentukan tingkat kesukaan penelis terhadap produk nata de yam yang dihasilkan. Produk nata de yam yang digunakan pada uji organoleptik adalah produk yang telah diberi penanganan tambahan setelah panen. Penanganan tambahan yang dilakukan yaitu perebusan, perendaman dan penambahan sirup agar produk layak dikonsumsi. Pada uji organoleptik ini sebanyak 25 orang penelis telah memberikan penilaian terhadap warna, aroma, rasa dan tekstur nata de yam dengan menggunakan skala hedonik 1-5. Skala 1 (sangat tidak suka), 2 (tidak suka), 3 (biasa), 4 (suka) dan 5 (sangat suka).

\section{Warna}

Pada produk pangan warna memiliki peranan yang sangat penting sebagai daya tarik yang paling utama oleh konsumen. Warna merupakan salah satu penilaian utama bagi konsumen untuk mengkonsumsi suatu produk. Warna yang dihasilkan dapat menjadi identitas bagi suatu produk pangan dan dapat menjadi acuan apakah produk tersebut layak untuk dikonsumsi. Setyaningsih et al, (2014) menyatakan warna yang terdapat pada suatu produk mempengaruhi penampakan sehingga meningkatkan daya tarik dan memberikan informasi yang lebih kepada konsumen tentang karakteristik makanan tersebut. Hasil uji organoleptik warna nata de yam dapat dilihat pada Tabel 9.

Tabel 9. Nilai Rata-rata Warna Nata de yam

\begin{tabular}{lc}
\hline Perlakuan & Nilai Warna \pm SD \\
\hline A = Tunas Tauge & $3,88 \pm 0,67$ \\
$\mathrm{~B}=$ Tauge segar & $4,08 \pm 0,64$ \\
$\mathrm{C}=$ Tauge akan busuk & $3,76 \pm 0,59$ \\
$\mathrm{D}=$ Tauge layu & $3,96 \pm 0,68$ \\
\hline
\end{tabular}

Berdasarkan Tabel 9 dapat dilihat tingkat kesukaan penelis terhadap produk nata de yam yang dihasilkan dengan menggunakan jenis tauge yang berbeda. Nilai kesukaan tertinggi diperoleh pada perlakuan B (tauge segar) sebesar 4,08 (suka), lalu disusul perlakuan D (tauge layu) sebesar 3,96 (biasa), selanjutnya pada perlakuan A (tunas tauge) sebasar 3,88 (biasa) dan yang terakhir perlakuan C (tauge akan busuk) sebesar 3,76 (biasa). 
Warna yang dihasilkan dalam pembuatan nata de yam berwarna putih bening. Warna nata yang dihasilkan dipengaruhi oleh warna media yang digunakan. Media pada pembuatan nata de yam berwarna putih dikarenakan bahan baku yang berwarna putih yang bersumber dari bengkuang dan tauge.

\section{Tekstur}

Salah satu parameter mutu untuk menentukan karakteristik nata de yam adalah tekstur yang dihasilkan. Tekstur atau kekenyalan suatu produk dipengaruhi oleh banyak sedikitnya serat. Semakin banyak kandungan serat maka semakin kenyal tekstur nata. Pada penelitian pembuatan nata de yam dengan penggunaan tauge yang berbeda menghasilkan tekstur yang berbeda tiap perlakuannya. Hasil uji organoleptik tekstur nata de yam dapat dilihat pada tabel 10.

Tabel 10. Nilai Rata-rata Tekstur Nata de yam

\begin{tabular}{ll}
\hline Perlakuan & Nilai Tekstur \pm SD \\
\hline A $=$ Tunas tauge & $3,92 \pm 0,76$ \\
$\mathrm{~B}=$ Tauge segar & $4,2 \pm 0,71$ \\
$\mathrm{C}=$ Tauge layu & $3,76 \pm 0,66$ \\
$\mathrm{D}=$ Tauge kering & $4,04 \pm 0,79$ \\
\hline
\end{tabular}

Berdasarkan tabel 10 dapat dilihat bahwa tingkat kesukaan penelis terhadap tekstur nata de yam dengan penggunaan tauge yang berbeda. Nilai kesukaan tertinggi diperoleh dari perlakuan B (tauge segar) yang bernilai 4,2 (suka), disusul oleh perlakuan D (tauge layu) yang bernilai 4,04 (suka), selanjutnya pada perlakuan A (tunas tauge) yang bernilai 3,92 (biasa) dan yang terendah pada perlakuan C (tauge akan busuk) yang bernilai 3,76 (biasa).

Dari pengujian tekstur dengan dengan menggunakan alat texture analyzer. Setiap perlakuan menghasilkan nilai yang berbeda, perlakuan D (tauge layu) dengan nilai tekstur sebesar 123,58 N/cm, disusul perlakuan $\mathrm{B}$ (tauge segar) dengan nilai $78,34 \mathrm{~N} / \mathrm{cm}$, selanjutnya perlakuan $\mathrm{C}$ (tauge akan busuk) dengan nilai 63,39 N/cm dan perlakuan A (tunas tauge) dengan nilai 47,17 N/cm. Dapat disimpulkan bahwa pada perlakuan D (tauge layu) merupakan nata dengan kekenyalan yang paling tinggi.

Penggunaan sumber nitrogen organik berupa tauge yang berbeda mempengaruhi tekstur nata yang dihasilkan. Tingkat kekenyalan nata erat kaitannya dengan kadar serat yang terkandung di dalam nata de yam. Semakin tinggi nilai tekstur pada nata maka serat kasar yang terkandung dalam nata semakin tinggi. Tidak hanya serat kasar, kekenyalan juga dipengaruhi oleh ketebalan nata yang diperoleh selama fermentasi. Semakin tebal nata yang dihasilkan maka tekstur nata berasa semakin kenyal sedangkan nata yang tipis maka tekstur nata tersebut lebih lunak. Dilihat dari kesukaan penelis yang tertinggi diperoleh pada perlakuan B (tauge segar) hal ini diduga karena kekenyalan yang tertinggi pada perlakuan $\mathrm{D}$ (tauge layu) kurang diminati penelis.

\section{Aroma}

Aroma merupakan satu faktor penting terhadap penerimaan penelis terhadap suatu produk pangan. Aroma suatu produk pangan sangat berpengaruh terhadap selera konsumen yang berkaitan dengan indera penciuman sehingga menimbulkan hasrat untuk mengkonsumsinya. Evaluasi aroma masih tergantung pada pengujian secara sensori. Produk nata de yam dengan penggunaan tauge yang berbeda menghasilkan aroma yang berbeda terhadap penelis. Hasil uji organoleptik aroma nata de yam dilihat pada Tabel 11.

Tabel 11. Nilai Rata-rata aroma Nata de yam

\begin{tabular}{ll}
\hline Perlakuan & Nilai Aroma \pm SD \\
\hline $\mathrm{A}=$ Tunas tauge & $3,56 \pm 0,65$ \\
$\mathrm{~B}=$ Tauge segar & $4,16 \pm 0,69$ \\
$\mathrm{C}=$ Tauge akan busuk & $3,52 \pm 0,59$ \\
$\mathrm{D}=$ Tauge layu & $3,64 \pm 0,99$ \\
\hline
\end{tabular}


Pada Tabel 11 dapat dilihat bahwa aroma produk yang paling disukai penelis adalah pada perlakuan B (tauge segar) bernilai 4,16 (suka), disusul perlakuan D (tauge layu) yang bernilai 3,64 (biasa), selanjutnya perlakuan A (tunas tauge) yang bernilai 3,56 (Biasa) dan yang terendah pada perlakuan C (tauge akan busuk) yang bernilai 3,52 (biasa). Pada produk nata de yam yang dihasilkan tidak memiliki perbedaan yang signifikan karena telah diberi perlakuan tambahan untuk menghilangkan aroma asam.

Nata merupakan salah satu produk fermentasi yang memiliki aroma yang asam ketika baru selesai dipanen. Aroma dari nata berbanding lurus dengan rasa pada nata. Tamimi et al (2015) menyatakan bahwa setelah penamenan nata perlu segera dilakukan peredaman dengan air dan sering diganti hingga aroma asam pada nata hilang dan dilakukan perebusan hingga mendidih. Dengan adanya penanganan tambahan seperti perebusan dan perendaman menyebabkan aroma asam yang terkandung didalam nata menjadi hilang. Sehingga dengan adanya perlakuan tambahan menyebabkan tidak terjadi perbedaan yang signifikan terhadap aroma didalam nata.

\section{Rasa}

Rasa merupakan faktor penting diterima atau tidaknya suatu produk pangan. Meskipun parameter lain seperti, aroma, tekstur dan warna telah memenuhi kriteria, namun jika rasa yang dihasilkan oleh produk tidak enak, maka produk tersebut tetap tidak dapat diterima konsumen. Nata de yam pada dasarnya hanya berasa hambar karena kandungan di dalamnya hanya berupa serat dan air. Untuk memberikan rasa pada nata maka ditambahkan sirup agar produk dapat dinikmati oleh penelis. Hasil uji organoleptik rasa nata de yam dapat dilihat pada Tabel 12.

Tabel 12. Nilai Rata-rata Rasa Nata de yam

\begin{tabular}{ll}
\hline Perlakuan & Nilai Rasa \pm SD \\
\hline $\mathrm{A}=$ Tunas tauge & $3,64 \pm 0,7$ \\
$\mathrm{~B}=$ Tauge segar & $3,8 \pm 0,65$ \\
$\mathrm{C}=$ Tauge layu & $3,6 \pm 0,65$ \\
$\mathrm{D}=$ Tauge kering & $3,72 \pm 0,94$ \\
\hline
\end{tabular}

Pada Tabel 12 dapat dilihat bahwa nilai skor tertinggi terhadap rasa diperoleh pada perlakuan B (tauge segar) dengan nilai 3,8 (biasa), disusul perlakuan D (tauge layu) dengan nilai 3,72 (biasa), selanjutnya perlakuan A (tunas tauge) dengan nilai 3,64 (biasa), yang nilai skor terendah pada perlakuan C (tauge akan busuk) bernilai 3,6 (biasa). Pada uji ini tidak terdapat berbedaan yang signifikan terhadap rasa disetiap perlakuan.

Penghidangan produk nata de yam pada penelitian ini dilakukan dengan penambahan sirup yang sama setiap perlakuan. Air sirup yang telah dibuat dengan formulasi yang sama direbus dengan nata selama 10 menit agar sirup dapat menyerap ke dalam nata dan memberikan rasa manis ketika dikonsumsi. Fifendy dan Annisah (2012) menyatakan umumnya rasa nata adalah tawar (hambar) sebelum ditambahkan sirup ataupun pemanis lainnya. Rasa yang berbeda pada produk yang dihasilkan disebabkan oleh ukuran potongan yang berbeda sehingga selama perendaman nata yang berukuran besar, air tidak mampu masuk sampai ke dalam sel-sel nata. Akibatnya nata yang dihasilkan akan terasa asam, sehingga pada saat pemasakan dengan penambahan sirup dengan jumlah yang sama pada setiap perlakuan menghasilkan nata yang hampar pada potongan nata yang besar dan sedikit manis pada nata yang potongan lebih kecil.

\section{KESIMPULAN}

Berdasarkan penelitian yang telah dilakukan diperoleh kesimpulan sebagai berikut:

1. Penggunaan tauge yang berbeda pada pembuatan nata de yam menghasilkan karakteristik berbeda pada kadar serat kasar, rendemen, ketebalan, berat, selulosa dan organoleptik nata de yam yang dihasilkan.

2. Berdasarkan hasil analisis fisik dan kimia yang dilakukan produk terbaik yang dihasilkan adalah pada perlakuan $\mathrm{D}$ (penggunaan tauge layu) dengan rata-rata serat kasar $(5,82 \%)$, ketebalan $(1,05$ $\mathrm{cm})$, berat $(335,07 \mathrm{~g})$, dan tekstur $(123,58 \mathrm{~N} / \mathrm{cm})$. 


\section{DAFTAR PUSTAKA}

Agustin. T. 2013. Gelatin Ikan: Sumber, Komposisi Kimia dan Potensi Pemanfaatannya. MEDIA Teknol. Has. Perikanan. doi: 10.35800/mthp.1.2.2013.4167.

Arifiani. N, Sani.T.A, dan Utami.A.Y.U.S. 2015. Peningkatan kualitas Nata De Cane dari Limbah Nira Tebu Metode Budchips dengan Penambahan Ekstrak Tauge sebagai Sumber Nitrogen. Bioteknologi. (12)2. 29-33. doi: 10.13057/biotek/c120201.

Evi.R, Pato. U dan Damanik.S.R. 2008. Optimalisasi Pemberian Ammonium Sulfat terhadap Produksi Nata De Banana Skin. J. Teknol. Pertan.(7)2.

Fifendy. M, Annisah.N. 2012. Kualitas Nata De Citrullus Meggunakan Berbagai Macam Starter. J. Sainstek. (4)2.158-164.

Hamad. A and Kristiono. 2013 . Pengaruh Penambahan Sumber Nitrogen Terhadap Hasil Fermentasi Nata De Coco. Progr. Stud. Tek. Kim. Fak. Tek. Univ. Muhammadiyah Purwokerto.(9)1.6265.

Hamad.A, Handayani. N. A, Puspawiningtyas. E. 2014. Pengaruh Umur Starter Acetobacter Xylinum Terhadap Produksi Nata De Coco ( Effects of the Starter Age of Acetobacter xylinum on the Nata de coco production). Progr. Stud. Tek. Kim. Fak. Tek. Univ. Muhammadiyah Purwokerto.(15)1.37-49.

Hastuti.W. 2015. Analisis Isoflavon dan Uji Aktivitas Antioksidan pada Tempe dengan Variasi Lama Waktu Fermentasi dan Metode Ekstraksi.

Kuncara. Y. A. D. 2017 . Pengaruh Penggunaan Filtrat Kecambah Kacang Kedelai sebagai Sumber Nitrogen terhadap Karakteristik Nata de Soya Berbahan Dasar Limbah Tahu.

Lempang. M. 2007. Fermentasi Nira Lontar Untuk Produk Nata. J. Penelit. Has. Hutan.(25)2. 147157.

Margaretha.Y. P. 2015. Pengaruh Kadar Gula terhadap Pembuatan Nata De Yam.

Masran.I. 2019. Pengaruh Penggunaan Jenis Gula yang Berbeda terhadap Karakteristik Nata De Yam yang Dihasilkan.

Maulana.A.I. 2010. Pengaruh Ekstrak Tauge (Phaseolus radiatus) Terhadap Kerusakan Sel Ginjal mencit (Mus musculus) yang Diinduksi Parasetamol.

Nur.A. 2009. Karakteristik Nata De Cottonii dengan Penambahan Dimetil Amino Fosfat (DAP) dan Asam Asetat Glacial.

Pambayun. R. 2002. Teknologi Pengolahan Nata de Coco.

Pertiwi.S.F, Aminah.S, Nurhidajah. 2013. Aktivitas Antioksidan, Sifat Kimia, dan Sifat Organoleptik Susu Kecambah Kedelai Hitam (Glycine Soja) Menurut Variasi Waktu J. Pangan dan Gizi. (04)08. 1-8.

Rosalia.L, Mustofa.A, dan Kurniawati.L. 2016. Aktivitas Antioksidan Nata De Rosela (Hibiscus sabdariffa L.) dengan Variasi Lama Ektraksi dan Berat Bunga Rosela. J. Teknol. Dan Ind. Pangan.(1)2. 107-115.

Setyaningsih.D, Apriyantono.A, Sari,M.P. 2014. Analisis Sensori untuk industri pangan dan argo. PT Penerbit IPB Press.

Suwijah. 2011. Pengaruh Kadar Gula, Vitamin C dan Kadar Serat Dari Sari Buah Markisa Ungu (Passiflora Edulis Var Edulis) pada Pembuatan Nata De Coco dengan Menggunakan Acetobacter xylinum.

Tamimi. A, Hs. A, Hendrawan.Y. 2015. Pengaruh Penambahan Sukrosa dan Urea terhadap Karakteristik Nata De Soya Asam Jeruk Nipis. Bioproses Komod. Trop.(3)1. 6-7.

Triyono. A. 2010. Mempelajari Pengaruh Penambahan Beberapa Asam pada Proses Isolasi Protein terhadap Tepung Protein Isolat Kacang Hijau (Phaseolus radiatus L.). Semin. Rekayasa Kim. dan Proses.1-9.

Wardhana. E, H. Rusmarilin, and E. Yusraini. 2016. Pengaruh Konsentrasi Gula Dan pH Terhadap Mutu Nata De Yammy Dari Limbah Cair Bengkuang. Rekayasa Pangan dan Pertan.(4)3. 323331.

Winarno. F. 2004. Kimia Pangan dan Gizi. Jakarta: PT. Gramedia Pustaka Utama.

Widajati. E. 2014. Dasar ilmu dan teknologi benih. PT Penerbit IPB Press.

Yeni. G, Failisnur, and Firdausni. 2013. Membuat Aneka Olahan Bengkuang. 